\title{
Social Media Marketing Strategy of Indonesian Tourism in The Time of Pandemic
}

\author{
Aulia Chloridiany* \\ Ministry of Tourism and Creative Economy, Indonesia \\ *Corresponding Author: aulia@indonesia.travel
}

DOI: https://doi.org/10.24922/eot.v8i1.71445

Article Info
Submitted
February $15^{\text {th }} 2021$
Accepted
March $18^{\text {th }} 2021$
Published
March $31^{\text {th }} 2021$

Article Info

\begin{abstract}
Tourism is among one of the hardest hit sectors caused by the Covid-19 pandemic. According to UNWTO (2020), 100-120 million direct tourism jobs were at risk and international tourist numbers in January - May 2020 decreased 56\% year on year. Indonesia's tourism sector is not an exception. The number of foreign tourist visits to Indonesia fell down $-89.22 \%$ year on year, which definitely affects the whole condition of Indonesian tourism. Therefore, the Indonesian government have done several efforts to manage the situation since the pandemic started. Due to limitation of offline activities, digital marketing, including social media, had become the main strategy to maintain Indonesian tourism's presence in the market. This paper will discuss the social media marketing strategy has been done by the Ministry of Tourism and Creative Economy (MOTCE) Indonesia to promote Indonesian tourism during pandemic time, especially for the global market. Using social media marketing strategy (SMMS) framework from Li, Larimo and Leonidou (2020), this research found that the social marketing media strategy has been implemented by MOTCE could be categorized as the social content strategy, as the Indonesia Travel accounts focus on suitable contents with the audiences who struggle with the pandemic. Indonesia Travel as the official social media marketing accounts, has been active to post contents even since the beginning of the pandemic through Facebook, Instagram, Twitter, Youtube, Weibo, and Wechat. From January to September 2020, Indonesia Travel posted more than 683 contents. However, the pandemic has driven the Indonesia Travel accounts to slightly changed the marketing objectives, adapting with what audiences wanted. Not only posting about the beauty of tourism destinations in Indonesia, since February they also post about Covid-19 related information.
\end{abstract}

Keywords: tourism, marketing strategy, digital marketing, social media, pandemic

\section{INTRODUCTION}

The COVID-19 disease was first emerged in Wuhan, China, in December 2019. Since then, the disease has spread http://ojs.unud.ac.id/index.php/eot all over the world until more than 44.7 million cases were founded as of October 2020 (Johns Hopkins University, 2020). On March 11 ${ }^{\text {th }}, 2020$, Director General of World Health Organization officially an- 
nounced the Covid-19 can be characterized as pandemic. Soon after the announcement, many countries have enforced travel restrictions.

As a consequence of the travel restrictions, tourism sectors suffered and became one of the hardest hit sectors caused by the Covid-19 pandemic. UNWTO (2020) predicts 100-120 million direct tourism jobs were at risk and USD 910 billion to 1.2 trillion in exports for tourism - international visitors' spending was lost. In fact, during January to May 2020, international tourist arrivals were decreased $56 \%$ year on year, means loss of USD 320 billion in exports from tourism in five months.

President of the Republic of Indonesia, Joko Widodo, announced the first Covid19 cases on March $2^{\text {nd }}, 2020$. A month later, the President decided to close the borders for visitors from all countries in order to curb the Covid19 imported cases (Jakarta Post, 2020). The decision was implemented in Regulation of Minister of Law and Human Rights of The Republic of Indonesia Number 11 Year 2020 Concerning Temporary Prohibition for Foreigner to Enter The Territory Of The Republic Of Indonesia, signed on April 2 $2^{\text {nd }}, 2020$.

In result, foreign visitors to Indonesia as of August 2020 were only 164.970 visits, declined drastically into $-89.22 \%$ year on year (MOTCE and Central Statistics Bureau, 2020). The decrease definitely affects the whole condition of Indonesian tourism. The Minister of Tourism and Creative Economy of the Republic of Indonesia (MOTCE), Wishnutama Kusubandio, stated that 13 million workers of tourism sectors as well as 32.5 million workers of indirectly-related-to-tourism were affected by pandemic (Detik, 2020).

Therefore, the Indonesian government have done several efforts to manage the situation since the pandemic started. Due to limitation of offline activities, digital marketing, including social media, had become the main strategy to maintain Indonesian tourism's presence in the market. As in the MOTCE official press release, Deputy Minister of Tourism Marketing, Nia Niscaya, stated that the online promotion and campaign should be optimized in order to build awareness in global markets (Kemenparekraf, 2020a).

Considering the above situation, this paper asks a main question: "What is the social media marketing strategy of Indonesian tourism during COVID 19 pandemic situation in 2020, especially for the global market?". Specifically, this paper digs the social marketing strategy has been done by the Ministry of Tourism and Creative Economy (MOTCE) of the Republic of Indonesia, which is in charge for the national tourism policy in Indonesia. Research period is from January to September 2020.

\section{LITERATURE REVIEW}

According to Kaplan and Haenlein (2010), "Social Media is a group of Internet-based applications that build on the ideological and technological foundations of Web 2.0, and that allow the creation and exchange of User Generated Content". Moreover, social media can be classified into: 1) collaborative projects (i.e., Wikipedia); 2) virtual communities (i.e., Twitter, TripAdvisor, travel blogs); 3) content communities (i.e., Youtube, Flickr, Pinterest, Instagram); 4) social network sites (i.e., Facebook, Linkedin); and 5) virtual games/ social worlds e.g., online games of Microsoft X-box or Sony Playstation and websites like Second Life) (Minazzi, 2015).

Meanwhile, social media for marketing purpose are defined as platforms on which people build networks and share information and/or sentiments (Kaplan and Haenlein, 2010). Social media have been admitted to change the marketplace drastically, therefore Li, Larimo and Leonidou (2020) conclude that social media marke- 
ting strategy (SMMS) as “an organization's integrated pattern of activities that, based on a careful assessment of customers' motivations for brand-related social media use and the undertaking of deliberate engagement initiatives, transform social media connectedness (networks) and interactions (influences) into valuable strategic means to achieve desirable marketing outcomes."

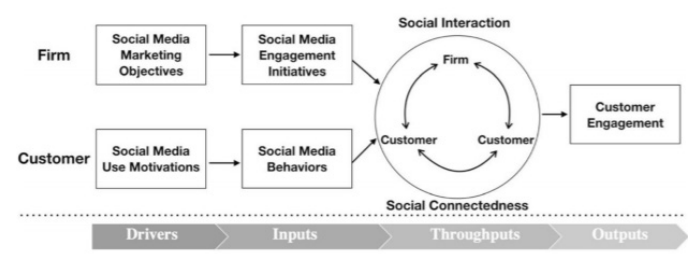

Figure 1. A conceptualization of the process of developing social media marketing strategies

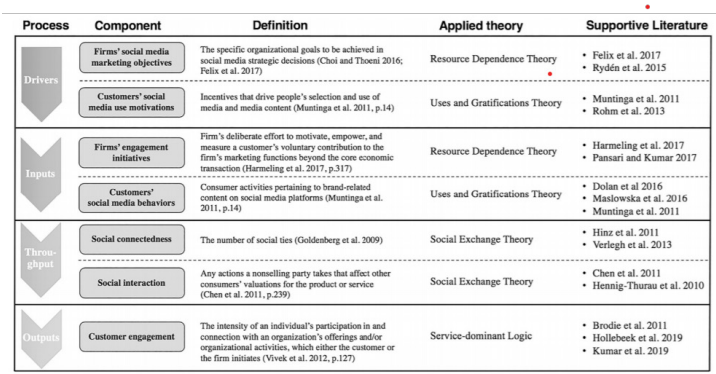

Figure 2. Theoretical anchoring of components constituting the process of developing social media marketing strategies

In addition, Li, et al. (2020) suggests three important criteria to differentiate SMMSs, i.e: 1) the nature of the firm's strategic social media objectives with regard to using social media; 2) the direction of interactions taking place between the firm and the customers; and 3) the level of customer engagement achieved. Besides, there were four categories of SMMS representing increasing levels of strategic maturity: 1) social commerce strategy; 2) social content strategy; 3 ) social monitoring strategy; and 4 social CRM strategy.

In the context of tourism, significances of social media marketing in tourism are: 1) Directing visitors and customers to the right travel information; 2) Sending personalize messages and content directly to interested segment of customers (Jashi, 2013). Moreover, Kotler, Bowen and Makens (2010) agrees that digital marketing, including social media, as the fastest-growing form of direct marketing. As he states, "For travel products, it can be argued that social media entails a change from one-toone recommendations from individuals to many-to-many conversations." But personalization is only one of some benefits of using social media, the others are: interactive; immediate and timely; cost effective; engagement and social sharing capabilities. On the other hand, the challenges are: results are hard to measure; and user controlled (Kotler, et al., 2010).

\section{METHODS}

This paper uses a qualitative case study approach. For a qualitative research, this study sought to explore and understand the meaning by individuals or group of people ascribed social or humanitarian issues (Creswell, 2013). The type of research is a case study. Qualitative research is a case study research strategy where researchers investigate carefully a program, event, activity, process, or group of individuals. The cases are limited by time, which is January to September 2020 period. Researchers collected detailed information using a variety of data collection procedures based on a predetermined time (Creswell, 2013). Data gathered in this research are from digital data, i.e. articles in websites, posts in social media, and social listening tools data.

\section{RESULTS AND DISCUSSION}

\section{Social Media under MOTCE}

The Indonesian government, in this case MOTCE, is officially in charge for some social media accounts. First, Kemen- 
parekraf (abbreviation of Kementerian Pariwisata dan Ekonomi Kreatif - MOTCE) as the official corporate accounts of the Ministry to inform public about the tourism and creative economy policy. Second, Pesona Indonesia Travel social media accounts to promote Indonesian tourism to Indonesian citizens, so that the accounts use Indonesian language. Third, Indonesia Travel social media accounts to promote Indonesian tourism to global markets. The social media accounts under MOTCE are mostly using Facebook, Instagram, Twitter, and Youtube, which can be classified as the virtual communities, content communities, and social network sites (Minazzi, 2015). The platform choices were also suitable with the world's most used social platforms like Facebook, YouTube, Instagram, WeChat, TikTok, and Twitter.

While Kemenparekraf serves general public as the corporate accounts, Pesona Indonesia Travel and Indonesia Travel fulfil the functions as the social media marketing channels for Indonesian tourism. However, Pesona and Indonesia Travel slightly have different purposes in terms of targeted audiences. Pesona Indonesia targeted Indonesian people to build networks and share information and/or sentiments (Kaplan and Haenlein, 2010; Li, et al., 2020), while Indonesia Travel targeted foreigners. The different target audiences bring different approaches, i.e Pesona Indonesia uses Indonesian language while Indonesia Travel uses English, Chinese, Japanese, Korean, Dutch, Deutsch, and Arabic.

\section{Indonesia Travel as the Official Social Media Accounts for Promoting Indone- sian Tourism to the Global Market}

To answer the research question, this paper focuses on the social media marketing strategy run by Indonesia Travel accounts. As explained before, the Indonesia Travel social media accounts were intended for global markets, in accordance with the Indonesian tourism's target markets. Indonesia travel accounts in Instagram, Twitter, and Youtube use only English for global users. While the Facebook account uses language in accordance with the IP Address, i.e. English (for global account), Japanese, Korean, French, Dutch, Deutsch, Russian, and Arabic. To serve Chinese market, Wechat and Weibo's social accounts were also made. In addition, this year MOTCE creates new Tiktok account, both for Global and Chinese Market.

\section{Performance of Indonesia Travel in 2019}

Under President Joko Widodo who has governed since 2014, tourism has been the leading sector of Indonesian economy. The marketing strategy of Indonesian tourism basically aims to build Branding Awareness - Selling of Indonesian tourism destinations. One of the marketing efforts is digital marketing, including social media. To attract and engage with more audiences, Indonesia Travel as the official social media marketing accounts implemented combination between User Generated Contents and contents those conformed with government policy.

According to 2019 MOTCE internal data, majority audience of @indtravel accounts comes from Generation Y, or commonly known as "Millennials". The global audiences loved the Indonesian tourism destinations, especially the natural ones, followed by cultural. Moreover, Bali is always the number one destination to visit in Indonesia, and has proven to attract audiences in every country from each platform.

\section{Indonesia Travel Social Media Market- ing Strategy in January - August/Sep- tember 2020}

This section shows the perspectives both from MOTCE or the Indonesian government through the social media contents as well as the customers which is reflected 
Table 2. Official Social Media Accounts Under the Ministry of Tourism and Creative Economy, Indonesia

\begin{tabular}{|c|c|c|c|c|}
\hline Name & $\begin{array}{l}\text { Content } \\
\text { Focus }\end{array}$ & $\begin{array}{l}\text { Targeted } \\
\text { Audience }\end{array}$ & Unit in Charge & Social Media Accounts \\
\hline $\begin{array}{l}\text { Kemen- } \\
\text { parekraf }\end{array}$ & $\begin{array}{l}\text { Informing } \\
\text { the gov- } \\
\text { ernment's } \\
\text { tourism and } \\
\text { creative } \\
\text { economy } \\
\text { policy }\end{array}$ & $\begin{array}{l}\text { Indonesian } \\
\text { and foreign } \\
\text { nationals }\end{array}$ & $\begin{array}{l}\text { Bureau of } \\
\text { Public Commu- } \\
\text { nication, under } \\
\text { the Secretary of } \\
\text { MOTCE }\end{array}$ & $\begin{array}{l}\text { Facebook: @ParekrafRI } \\
\text { Instagram: @kemenparekraf. } \\
\text { ri } \\
\text { Twitter:@Kemenparekraf } \\
\text { Youtube:@Kemenparekraf } \\
\text { Tiktok:@Kemenparekraf }\end{array}$ \\
\hline $\begin{array}{l}\text { Pesona } \\
\text { Indonesia } \\
\text { Travel }\end{array}$ & $\begin{array}{l}\text { Promoting } \\
\text { Indonesian } \\
\text { tourism }\end{array}$ & $\begin{array}{l}\text { Indonesian } \\
\text { citizens } \\
\text { Consum- } \\
\text { ers/ Tour- } \\
\text { ists (G to } \\
\text { C) }\end{array}$ & $\begin{array}{l}\text { Directorate } \\
\text { of Marketing } \\
\text { Communica- } \\
\text { tion, under the } \\
\text { Deputy Minis- } \\
\text { ter of Tourism } \\
\text { Marketing }\end{array}$ & $\begin{array}{l}\text { Facebook: @pesonaidtravel } \\
\text { Instagram: @pesonaid_travel } \\
\text { Twitter:@pesonaid_travel } \\
\text { Youtube:@pesonaindone- } \\
\text { siaofficial }\end{array}$ \\
\hline $\begin{array}{l}\text { Indo- } \\
\text { nesia } \\
\text { Travel }\end{array}$ & $\begin{array}{l}\text { Promoting } \\
\text { Indonesian } \\
\text { tourism }\end{array}$ & $\begin{array}{l}\text { Foreign } \\
\text { nationals } \\
\text { Consum- } \\
\text { ers/ Tour- } \\
\text { ists (G to } \\
\text { C) }\end{array}$ & $\begin{array}{l}\text { Directorate } \\
\text { of Marketing } \\
\text { Communica- } \\
\text { tion, under the } \\
\text { Deputy Minis- } \\
\text { ter of Tourism } \\
\text { Marketing }\end{array}$ & $\begin{array}{l}\text { Facebook:@Indonesia. } \\
\text { Travel } \\
\text { Instagram: @indtravel } \\
\text { Twitter: @indtravel } \\
\text { Youtube: @indonesiatravel } \\
\text { Wechat: indtravel } \\
\text { Weibo : } \\
\text { Tiktok: @Indonesia.travel } \\
\text { and indonesia.travel } \\
\end{array}$ \\
\hline
\end{tabular}

through Sprinklr social listening tools data. The best post contents were taken from Indonesia Travel's Twitter accounts which has the biggest number of followers among with other Indonesia Travel social media accounts (1.3 million followers). Meanwhile, Sprinkl captures data related with Indonesia Tourism keywords.

\section{January 2020}

When the first pandemic news in China reached Indonesia, the government as well as the people of Indonesia didn't really aware that this disease would spread here. Thus, business run as usual. So does Indonesia.travel as the official social media accounts to promote Indonesian tourism for the global market. Looking back at Indonesia Travel's contents on January 2020, posts' details were as follows: 26 in Instagram, 4 in Youtube, 12 in Facebook, and 11 in Twitter. From those posts, all were about Indonesian tourism destinations and special events, e.g. Chinese New Year.

On the other hand, from customers' perspectives, there was no significant turmoil. Sentiment Index on Indonesia Tourism topic captured by Sprinklr (January, 2020) shows that from 20 target markets, only Australia gets low score which is $27,12 \%$. According to this data, the other markets' scores were above 50\% which 
Table. 3. Description of Indonesia Travel Social Media Accounts

\begin{tabular}{|c|c|c|c|}
\hline Platforms & Accounts & Language & Target Markets \\
\hline \multirow[t]{8}{*}{ Facebook } & @Indonesia.Travel & English & Global \\
\hline & & Japanese & Japan \\
\hline & & Korean & South Korea \\
\hline & & French & France \\
\hline & & Dutch & The Netherland \\
\hline & & Deutsch & Germany \\
\hline & & Russian & Russia \\
\hline & & Arabic & $\begin{array}{l}\text { Saudi Arabia, United Emirates of } \\
\text { Arab, Middle East countries }\end{array}$ \\
\hline Instagram & @indtravel & English & Global \\
\hline Twitter & @indtravel & English & Global \\
\hline YouTube & @indonesiatravel & English & Global \\
\hline WeChat & 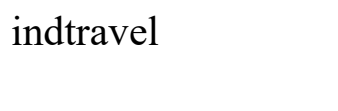 & Chinese & China \\
\hline Weibo & QWXXX & Chinese & China \\
\hline \multirow{2}{*}{$\begin{array}{l}\text { Tiktok } \\
\text { (Douyin in } \\
\text { Chinese) }\end{array}$} & @Indonesia.travel & $\begin{array}{l}\text { Indonesian } \\
\text { and English }\end{array}$ & Global (including Indonesia market) \\
\hline & $\begin{array}{l}\text { indonesia.travel } \mathrm{Q} \\
\end{array}$ & Chinese & China \\
\hline
\end{tabular}

\section{Best Posts}

Twitter

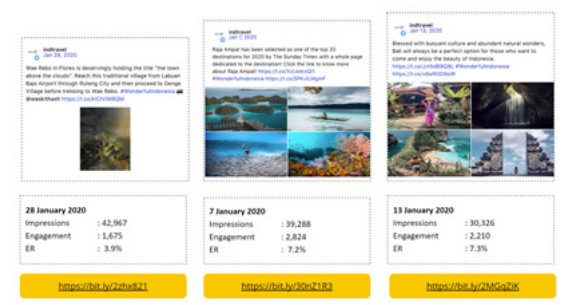

Figure 3. Indonesia.Travel Social Media Contents on January 2020

means good.

\section{February 2020}

However, in February, the pandemic tension started to feel in Indonesia. The Indonesian government issued Advisory on Covid19 and suspending direct flights from and to China on February $5^{\text {th }} 2020$. MOT$\mathrm{CE}$ also issued Official Statement regarding Covid19, which published as the first article in special page of the Indonesian

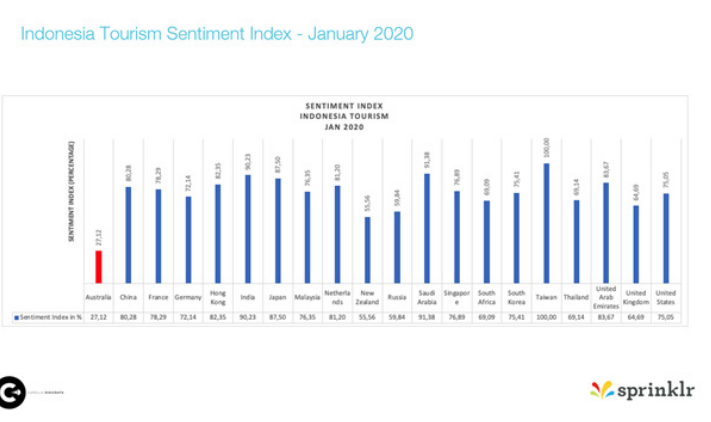

Figure 4. Indonesia Tourism Sentiment Index by Sprinklr, January 2020

tourism promotion website, www.indonesia.travel/coronavirus. The contents related to Covid19 appeared as the best post of Indonesia Travel's twitter account in February 2020, which had 40,366 impressions and got good engagement rate, $5.8 \%$. While Sentiment Index on Indonesia Tourism topic captured by Sprinklr (February, 2020) shows three countries got low score, which were Singapore (47.5\%), South Africa $(39.03 \%)$, and Thailand $(47.89 \%)$. 


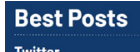

Iwitter
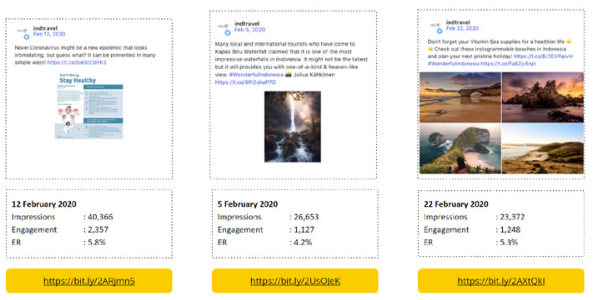

Figure 5. Indonesia.Travel Social Media Contents in February 2020

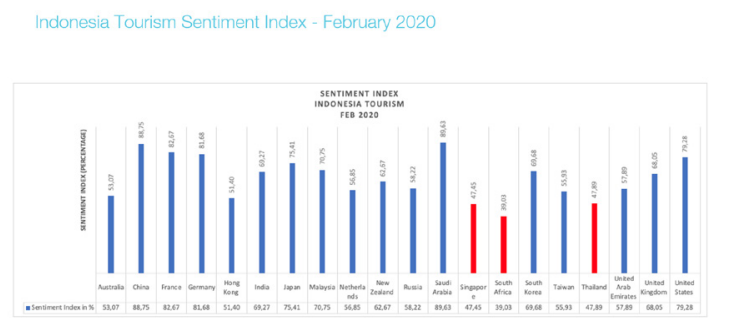

$\odot$

Y.sprinklr

Figure 6. Indonesia Tourism Sentiment Index by Sprinklr, January 2020

\section{March 2020}

In March, the social listening tools showed worrying data that 7 of 20 countries got low score of sentiment index: Australia, Hongkong, Malaysia, New Zealand, Russia, Singapore, and United States. On the other hand, Indonesia Travel's social media accounts kept posting about Covid19 related information as well as Indonesian tourism destinations.

\section{Best Posts}

Twitter

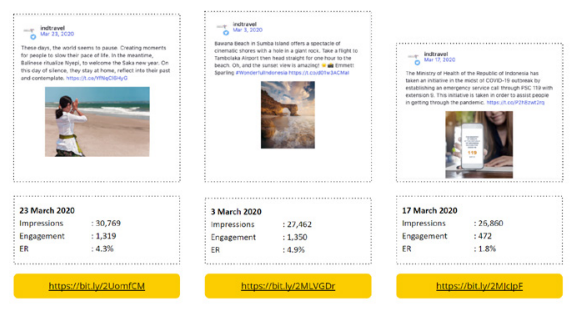

Figure 7. Indonesia.Travel Social Media Contents in March 2020

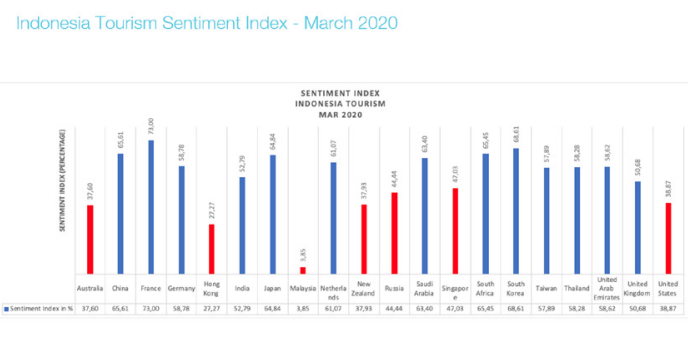

Q

Y.sprinklr

Figure 8. Indonesia Tourism Sentiment Index by Sprinklr, March 2020

\section{April 2020}

In April, the social listening tools showed worse conditions that 9 of 20 countries got low score of sentiment index: Australia, Hongkong, Germany, Malaysia, Netherlands, South Africa, Thailand, United States, and United Kingdom. New Zealand, Russia, Singapore, and United States. Meanwhile, MOTCE changed the Wonderful Indonesia branding into Thoughtful Indonesia, to show empathy on the pandemic situation. The government also pushed the Stay at Home campaign to curb the virus spread. Furthermore, MOTCE followed the Travel Tomorrow campaign initiated by UNWTO. Those all policies were translated into below social media posts.

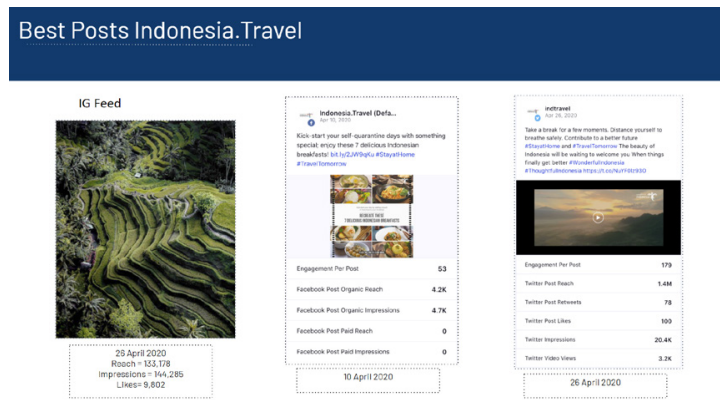

Figure 9. Indonesia.Travel Social Media Contents in April 2020 
Indonesia Tourism Sentiment Index - April 2020

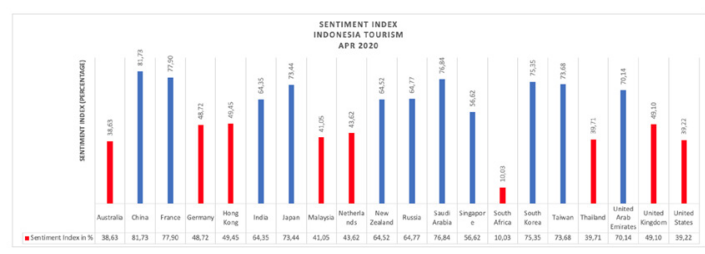

()

\%/sprinklr

Figure 10. Indonesia Tourism Sentiment Index by Sprinklr, April 2020

\section{May 2020}

In May, the Indonesia Travel social media accounts got steady with the \#StayAtHome \#TravelTomorrow \#ThoughtfuIIndonesia hashtags, while still showing the beauty of Indonesian tourism destination contents. In the meantime, the social listening tools showed relieving conditions that 19 of 20 countries had high score of sentiment index. It means that the targeted markets had positive perceptions of Indonesia tourism topics.

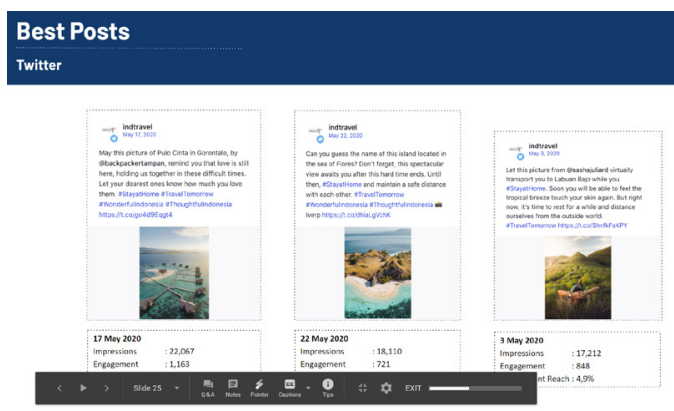

Figure 11. Indonesia.Travel Social Media Contents, May 2020

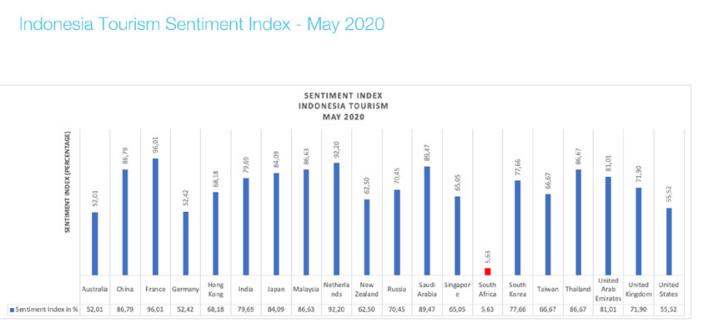

○

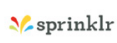

Figure 12. Indonesia Tourism Sentiment Index by Sprinklr, May 2020

\section{June 2020}

In June, there is no big changes of government policy towards foreign tourists. Therefore, the Indonesia Travel social media accounts continued the previous pattern, posting Indonesian tourism destinations with \#StayAtHome \#TravelTomorrow \#ThoughtfulIndonesia hashtags. The social listening tools also showed stable condition, with 18 of 20 countries got high score of sentiment index.

\section{Best Posts}

Twitter

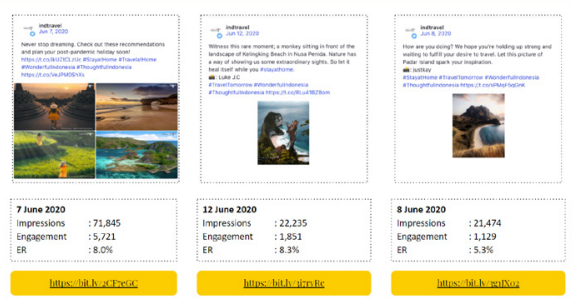

Figure 13. Indonesia.Travel Social Media Contents, June 2020

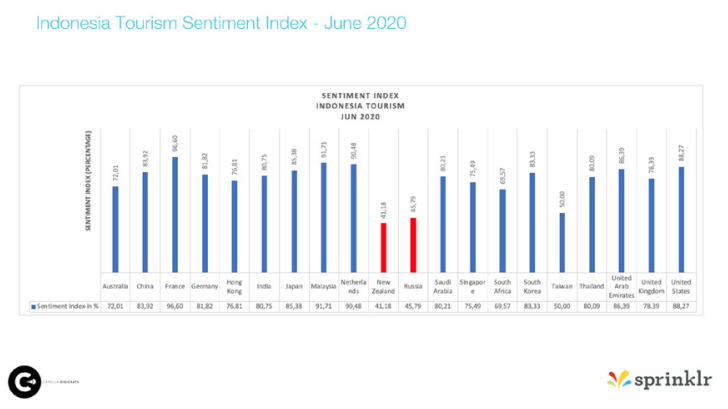

Figure 14. Indonesia Tourism Sentiment Index by Sprinklr, June 2020

July 2020

In July, the Indonesia Travel social media accounts continued the previous campaigns and the social listening tools showed 17 of 20 countries had high score of sentiment index, meaning that global markets still had positive perceptions of Indonesian tourism. 
Best Posts Iwitter

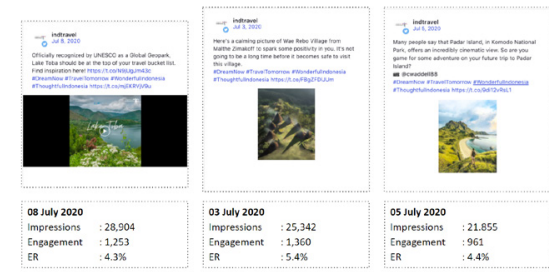

Figure 15. Indonesia.Travel Social Media Contents, July 2020

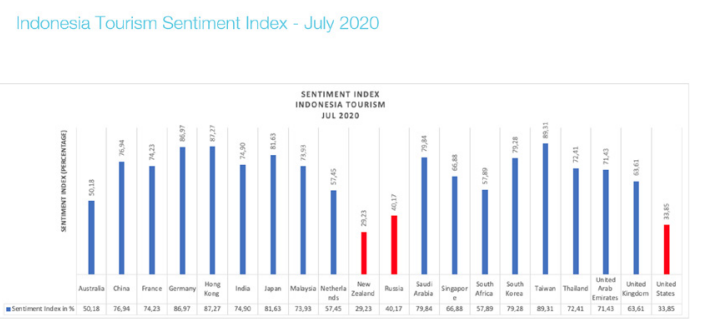

Q

S. sprinklr

Figure 16. Indonesia Tourism Sentiment Index by Sprinklr, July 2020

\section{August 2020}

There is no big change of the social media campaign for international market this month. The social listening tools also showed the stable condition with 17 of 20 countries had high score of sentiment index.

\section{Best Posts Twitter}

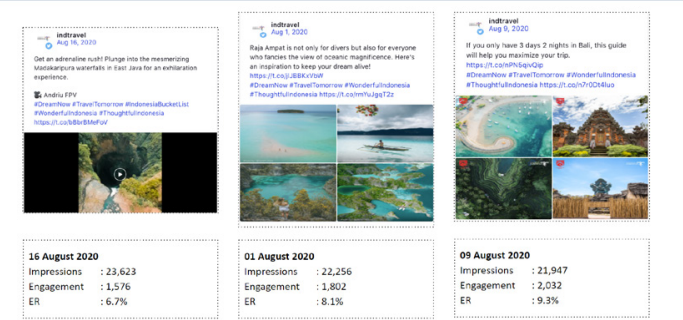

Figure 17. Indonesia.Travel Social Media Contents, August 2020
Indonesia Tourism Sentiment Index - August 2020

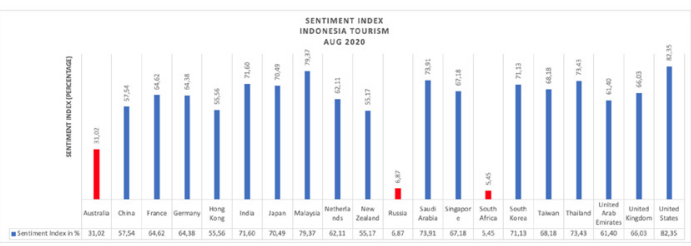

()

\%sprinklr

Figure 18. Indonesia Tourism Sentiment Index by Sprinklr, August 2020

\section{September 2020}

In September, the Indonesia Travel social media accounts introduced a new campaign style with asking an international influencer who stay in the country to join the campaign. As a result, the posts about the influencer became the best post in Indonesia Travel's Instagram account this month.

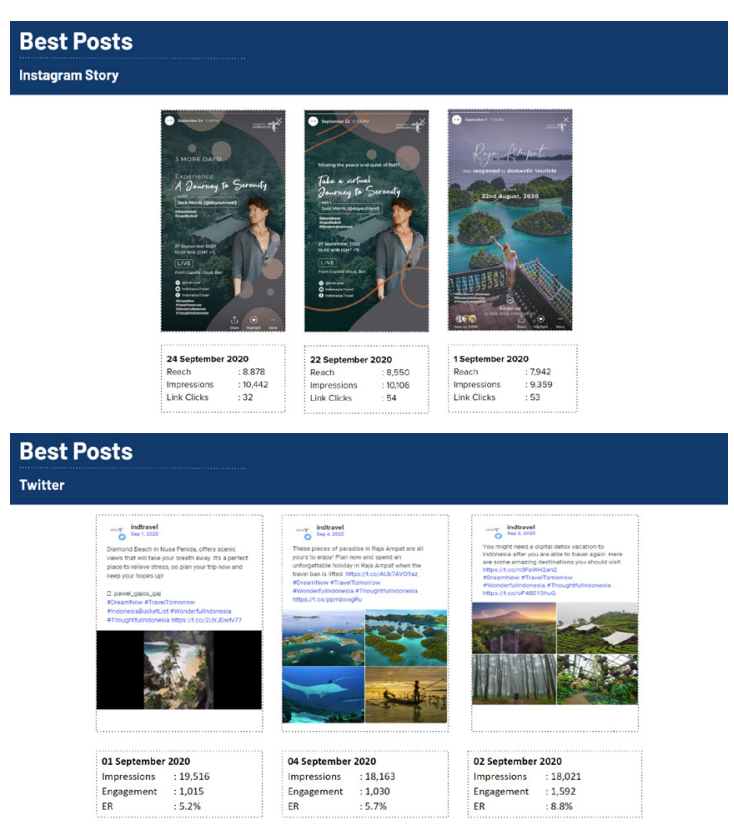

Figure 13. Indonesia.Travel Social Media Contents, September 2020 
Indonesia Travel Social Media Marketing Strategy during Covid-19 Pandemic: An Analysis

From the above social media contents as well as social listening tools data, this paper would discuss and analyze how the social media marketing strategy developed by Indonesia Travel based on Li, Larimo and Leonidou (2020) framework.

\section{Drivers}

The Indonesian government considers tourism as one of the leading sectors in the country. Therefore, all efforts have been done by MOTCE to support the sector, especially the marketing one. The marketing strategy of Indonesian tourism basically aims to build Branding - Awareness - Selling of Indonesian tourism destinations. It was achieved through combination of offline marketing activities (i.e. events, sales missions, festivals) and digital ones. One of the important digital marketing strategies was promoting Indonesian tourism through social media channels. In Indonesian case, the social media channel to promote Indonesian tourism for the global markets is Indonesia Travel. Targeting those who will visit Indonesia (G2C), Indonesia Travel opens many social media accounts based on market preferences, i.e. Instagram, Facebook, Youtube, Tiktok, WeChat, and Weibo. However, the pandemic situation forced the Indonesian government to stop all offline activities, especially when the country's borders were all closing in April 2020. Indonesian couldn't promote tourism destinations abroad as well as foreigners couldn't come to Indonesia for uncertain times. The situation forced the government to change slightly the marketing objective, currently only to maintain the awareness of Indonesian tourism destinations in potential tourists' minds. As stated by Deputy Minister of Tourism Marketing, Nia Niscaya, the online promotion and campaign should be optimized in order to build awa- reness in global markets. Hence, it is the time for Indonesia Travel has become the backbone to present Indonesian tourism to the world.

On the other hand, the motivations from potential tourists from all over the world also has changed since the pandemic started early this year, especially due to the travel restrictions. They were curious about the pandemic situation in tourism destinations, including in Indonesia. Referring to the social listening tools MOTCE used, Sprinklr, there were worrying situation at the beginning of the pandemic when more and more target countries got low scores of sentiment index when we talked about Indonesia Tourism topics in social media environment. In January, there was only Singapore which got sentiment score under $50 \%$. In February, there were three countries; in March, there were 7 (seven) of 20 (twenty) countries; and in April, there were 9 (nine) which had low sentiment scores toward Indonesian tourism. Those numbers mean that the countries had negative perceptions about Indonesian tourism destinations, probably related with the Covid19 situation here. Therefore, the bad situation must be responded with the right action.

\section{Inputs}

Implementing the new direction from government as well as responding on the digital users' behaviours during pandemic, MOTCE through the Indonesia travel social media team initiated to engage with audience through: Posting more information about the current situation regarding $\mathrm{CO}$ VID19 in Indonesia that may be needed by the audiences. Information here are including about the immigration or visa, flights, and closed tourist attractions. The detailed articles were published in special landing page Indonesia.travel/coronavirus, so that the social media users can access the site. This initiative has started since February 2020 until now. 
Changing the Wonderful Indonesia logo into Thoughtful Indonesia on April $23^{\text {rd }}, 2020$ to show empathy on the current pandemic situation (Kemenparekraf, 2020c). Furthermore, the logo changing also inspired the the Indonesia Travel's social media contents to be more emphatic to the audience, not to ask them to travel for now. This kind of tone still have been implemented until now.

Riding the wave on \#StayAtHome campaign while introducing activities at home related with Indonesian tourism and creative economy. For example: how to cook Indonesian food; how to create Indonesian traditional handicrafts; etc. The campaign has been held from April to June 2020.

Following \#DreamNow \#TravelTomorrow hashtag initiated by UNWTO while posting User Generated Content photos of tourism destinations in Indonesia, from April to this time.

Supporting \#InDOnesiaCARE movement, a policy made by MOTCE originally for the tourism industry (G2B) on July $10^{\text {th }}$, 2020 (Kemenparekraf, 2020b). This movement was intended to implement Cleanliness, Healthy, Safety, and Environment Sustainability (CHSE) protocols in tourism attractions as well as accommodations in Indonesia.

Initiating \#FromIndonesiaWithLove campaign for the global market as directed by Minister of Tourism and Creative Economy in September 2020.

From customers' perspectives, we can see that the social media user's behaviors towards Indonesia tourism issues has become relatively positive from May to September 2020. From 20 target countries, in May 2020 there was only one country which had low score under $50 \%$; then in June 2020 there were two countries; in July 2020 there were three countries; and in August there were three countries.

\section{Throughputs}

This phase is explained by social connectedness as well as social interaction between the government, which is represented by Indonesia Travel as the official social media accounts, and the customer, which are the followers.

During pandemic, Indonesia Travel accounts has been still active. Total they post 683 contents from January to September 2020 through: 93 Facebook posts; 312 Instagram posts (Instagram feeds, Instagram stories, Instagram TV); 266 Twitter posts; 12 Youtube videos.

The contents posted were also varied in order to connect and interact with the audiences, i.e.: UGC photos; Interactive quiz; Interview with the international influencer who lives in Indonesia; etc.

\section{Outputs}

In 2019, Indonesia Travel followers liked most about Indonesian natural tourism destinations and their favourite one is Bali. But, at the early phase of the pandemic, they wanted more information about Covid19 related information, i.e. immigration or visa, current condition of Covid-19 cases in Indonesia, etc. Indeed, according to the best posts of Indonesia Travel' Twitter account in February and March, contents about Covid19 related information were most likeable. It means that the inputs given by Indonesia Travel were matching with what audiences wanted.

Moreover, from March to September 2020, the audiences tended to be bored with Covid19 related posts and they liked tourism destination contents more. Although Indonesia Travel has never asked the audience to have holiday during pandemic, the audiences still like and comment on the posts. It might be considered that they miss traveling to destinations like Indonesia. If we looked at the Engagement Rates of the content posted in Indonesia Travel 
social media accounts, the best post is related with Indonesian tourism destinations, about 3 days 2 nights plan in Bali, which reaches $9.3 \%$ point.

\section{CONCLUSION}

The Covid-19 pandemic shook tourism industry like no other crises. The travel restrictions to curb the disease spreading had implication to the drastic decrease of international tourist visitors, tourism exports, and jobs loss. Indonesia was no exception. Due to the closing borders, international tourists from January to August fell down $-89.22 \%$ year on year.

However, even during pandemic, the Indonesian government didn't stop the marketing activities to promote Indonesian tourism for the global market. Because of the limitation of offline activities, digital marketing - especially social media - has become the backbones of Indonesia's tourism marketing efforts. Indonesian government, in this case is MOTCE, used the official social media marketing accounts, namely Indonesia Travel, to promote Indonesian tourism through Facebook, Instagram, YouTube, Twitter, WeChat, and Weibo. From January to September 2020, Indonesia Travel posted 683 contents through the accounts.

The pandemic has driven the Indonesia Travel accounts to slightly changed the marketing objectives, adapting with what audiences wanted. Not only posting about the beauty of tourism destinations in Indonesia, since February they also post about Covid-19 related information. For 3 (three) months, the audiences liked this kind of contents. However, from May to September, those potential tourists returned to like and comment the tourism destinations, although Indonesia Travel has never asked followers to travel during pandemic.

According to $\mathrm{Li}$, et al, (2020), the social marketing media strategy has been implemented by MOTCE during pandemic could be categorized as the social content strategy, as the Indonesia Travel accounts focus on suitable contents with the audiences who struggle with the pandemic.

\section{REFERENCES}

Creswell, J. W. (2013) Qualitative Inquiry and Research Design Choosing among Five Approaches. Third Edition. United States of America: SAGE Publications Ltd.

Detik (2020) Wishnutama Gambarkan Kondisi Pariwisata yang Babak Belur Dihantam Corona. Available at: https://travel.detik.com/ travel-news/d-5017196/wishnutamagambarkan-kondisi-pariwisata-yangbabak-belur-dihantam-corona (Accessed: 30 November 2020).

Jakarta Post (2020) Indonesia bans entry of foreigners to curb spread of coronavirus. Available at: https://www. thejakartapost.com/news/2020/03/31/ indonesia-bans-entry-of-foreignersto-curb-spread-of-coronavirus.html (Accessed: 30 November 2020).

Jashi, C. (2013, May). Significance of social media marketing in tourism. In 8th Silk Road International Conference "Development of Tourism in Black and Caspian Seas Region”. Tbilisi: Black Sea University Publishing (pp. 37-40).

Johns Hopkins University (2020) COVID-19 Dashboard by the Center for Systems Science and Engineering (CSSE) at Johns Hopkins University (JHU).

Kaplan, A. M. and Haenlein, M. (2010) 'Users of the world, unite! The challenges and opportunities of Social Media', Business horizons, 53(1), pp. 59-68. 
Kemenparekraf (2020a) Siaran Pers: Kampanye Pariwisata Indonesia Secara Daring Dioptimalkan Selama Masa Pandemi. Available at: https:// www.kemenparekraf.go.id/post/siaran-pers-kampanye-pariwisata-indonesia-secara-daring-dioptimalkanselama-masa-pandemi (Accessed: 30 November 2020).

Kemenparekraf (2020b) Siaran Pers : Kemenparekraf Luncurkan Kampanye Penerapan Protokol Kesehatan 'Indonesia Care”. Available at: https:// www.kemenparekraf.go.id/post/siaran-pers-kemenparekraf-luncurkankampanye-penerapan-protokol-kesehatan-indonesia-care (Accessed: 30 November 2020).

Kemenparekraf (2020c) Siaran Pers: Logo Thoughtful Indonesia Sementara Digunakan di Masa Pandemi. Available at: https://www.kemenparekraf.go.id/ post/siaran-pers-logo-thoughtful-in- donesia-sementara-digunakan-di-masa-pandemi (Accessed: 30 November 2020).

Kotler, P., Bowen, J. T. and Makens, J. C. (2010) Marketing for Hospitality and Tourism (Fifth Edition). New Jersey: Pearson Prentice Hall.

Li, F., Larimo, J., \& Leonidou, L. C. (2020). Social media marketing strategy: definition, conceptualization, taxonomy, validation, and future agenda. Journal of the Academy of Marketing Science, $1-20$.

Minazzi, R. (2015) 'Social Media Marketing in Tourism and Hospitality'.

MOTCE and Central Statistics Bureau (2020) Data Kunjungan Wisatawan Mancanegara Bulanan Tahun 2020.

UNWTO (2020) 'International tourism faces deepest crisis in history ${ }^{\prime}$, World Tourism Barometer. 